\title{
Assessment of Anti-proliferative Effect of Extract Fractions of Euphorbia neriifolia Leaves in Human Prostate Adenocarcinoma DU-145 Cells
}

\author{
P. Y. MALI* AND S. GOYAL
}

Department of Pharmacology, B. R. Nahata College of Pharmacy, Mandsaur University, Mandsaur, Madhya Pradesh 458001, India

Mali et al.: Anti-proliferative Effect of Euphorbia neriifolia Leaves in DU-145 Cells

Euphorbia neriifolia Linn. Sp. Pl. (451.1753) belonging to family Euphorbiaceae has several ethnomedicinal uses. To authenticate these uses scientifically, we have assessed anti-proliferative effect of extract fractions of Euphorbia neriifolia leaves in human prostate adenocarcinoma DU-145 cells by 3-[4,5-dimethylthiazol2-yl]-2,5-diphenyl tetrazolium bromide cell proliferation assay. 3-[4,5-dimethylthiazol-2-yl]-2,5-diphenyl tetrazolium bromide cell proliferation assay was used for assessment anti-proliferative effect of extract fractions of Euphorbia neriifolia leaves in human prostate adenocarcinoma DU-145 and normal (Vero) cells. The cells were treated with series of concentrations of extract fractions $(4.12-1000 \mu \mathrm{g} / \mathrm{ml}) \mathrm{for}$ $48 \mathrm{~h}$. Doxorubicin was considered as standard anti-cancer drug. In order to inhibition concentration and Selectivity Index results, extract fractions have been classified into 05 categories as described by Prayog et al. No extract fraction (EN1 to EN6) of Euphorbia neriifolia leaves was found in first 02 categories at the tested concentrations. Only doxorubicin standard drug sample was found in second category. It can be concluded that no other cells studies were documented yet on isolates and extract fractions of Euphorbia neriifolia by in vitro methods except murine B16F10 melanoma cells. Therefore, there is a need to carry forward these studies at higher concentrations of extract fractions (EN1 to EN6) in same and other adenocarcinoma cells. It can also be study by using other in vivo allograft and xenograft experimental models to confirm anti-proliferative or anti-cancer effects of these extract fractions.

Key words: Anti-proliferative effect, DU-145 cells, Euphorbia neriifolia Leaves, Extract fractions, MTT cell proliferation assay

Euphorbia neriifolia (E. neriifolia) is worldwide scattered in Baluchistan, Burma, India and Malaysian Islands. In India, it is found in rocky ground throughout Deccan Peninsula and Orissa. It is habitually cultivated for hedges in villages all over India ${ }^{[1,2]}$. E. nerrifolia

*Address for correspondence E-mail: pymali2008@rediffmail.com
This is an open access article distributed under the terms of the Creative Commons Attribution-NonCommercial-ShareAlike 3.0 License, which allows others to remix, tweak, and build upon the work non-commercially, as long as the author is credited and the new creations are licensed under the identical terms

Accepted 14 December 2020

Revised 01 October 2020

Received 09 July 2020

Indian J Pharm Sci 2020;82(5):912-917 
has several ethnomedicinal uses. The latex of E. nerrifolia is an active ingredient of many Ayurvedic formulations like Abhaya lavana, Avittoladi bhasma, Citrakadi taila, Jatyadi varti, Snuhidugdhadi varti, Snuhi ghrta and Jalodarari ras. E. neriifolia has been traditionally indicated in Vatavyadhi, Gulma, Udara, Sula, Sotha, Arsas, Kusta and Medoroga ${ }^{[3,4]}$. Latex is acrid, laxative, pungent and good for treatment of tumors, abdominal troubles and leucoderma. It is also used as a purgative, rubefacient, carminative, expectorant, whooping cough, gonorrhea, leprosy, asthma, dyspepsia, and jaundice, enlargement of the spleen, colic and stone in the bladder. It is used to remove cutaneous eruptions and warts ${ }^{[1,5]}$. Leaves are brittle, heating, carminative, improve the appetite, good for treatment of tumors, pain, inflammation, abdominal swelling and bronchial infection ${ }^{[5]}$. The leaves of E. neriifolia extract and its isolates have been reported scientifically using various in vivo and in vitro experimental methods for anti-carcinogenic ${ }^{[6-8]}$ and cytotoxicity ${ }^{[9,10]}$ properties. The leaves of E. neriifolia is reported to have phytochemicals such as kaempferol ${ }^{[11]}$, taraxerol[12], euphol ${ }^{[13]}$, quercetin and rutin ${ }^{[14]},(24 \mathrm{R})$ cycloartane-3 $\beta, 24,25$-triol,5,4' -dihydroxy-3, 7,3',5' tetramethoxyflavone, pachypodol, combretol ${ }^{[15]}$, 2-(3,4-dihydroxy-5-methoxy-phenyl)-3, 5-dihydroxy6,7-dimethoxychromen-4-one ${ }^{[16,17]}$, etc. Prostate Carcinoma ( $\mathrm{PCa})$ is the $2^{\text {nd }}$ most common cause of cancer and $6^{\text {th }}$ leading cause of cancer death among men worldwide ${ }^{[18]}$. Molecular mechanisms underlying onset and progression of PCa was not fully understood, but the factors implicated in pathogenesis of this disease include age, race, diet, androgen secretion and metabolism and activated oncogenes ${ }^{[19-21]}$. The search for efficient mode of prevention is presently in progress. Recently studies have shown that the use of Pomegranate Juice (PJ) components consists of luteolin, ellagic acid and punicic acid together inhibit the growth of hormone-dependent and hormone-refractory prostate cancer cells and inhibit their migration ${ }^{[22]}$. Additionally, Bhandari has reviewed the beneficial role of pomegranate in other disorders including prostate cancer $^{[23]}$. In reference with these studies, the role of E. neriifolia leaves in human prostate adenocarcinoma DU-145 cells was not evaluated yet. Therefore, the present study was an effort to assess anti-proliferative effect of extract fractions of E. neriifolia leaves in human prostate adenocarcinoma DU-145 and normal (Vero) cells using 3-[4,5-dimethylthiazol-2-yl]-2,5diphenyl tetrazolium bromide (MTT) cell proliferation assay. The E. neriifolia plant and its leaves (Fresh and well grown) were collected from local region of Bhopal, Madhya Pradesh, India. The taxonomist, Dr. Vijay V. Bhadane, Department of Botany, Pratap College, Amalner-425401, Maharashtra, India was authenticated the plant. Voucher specimen (No. PCA/ Bot-P1637) was assigned and deposited in the same. The detailed procedure of extraction and fractionation of $E$. neriifolia leaves was mentioned in earlier report of Mali et al. ${ }^{[24]}$. The extract fractions obtained were concentrated, dried and designated as EN1 (Petroleum ether extract fraction), EN2 (Toluene extract fraction), EN3 (Chloroform extract fraction), EN4 (Ethyl acetate extract fraction), EN5 (n-butanol extract fraction) and EN6 (Aqueous extract fraction) use for further studies. The stock solutions of extract fractions was prepared by weighing accurately $10 \mathrm{mg}$ of each extract fraction and dissolved into $1 \mathrm{ml}$ of Dimethyl sulfoxide (DMSO) solution, i.e. $10 \mathrm{mg} / \mathrm{ml}$ and diluted with culture medium. The final working concentrations of each extract fractions were achieved $1000 \mu \mathrm{g} / \mathrm{ml}$. The human prostate adenocarcinoma (DU-145) and normal (Vero) epithelial cells (American Type Culture Collection, USA) were procured from the National Centre for Cell Science, Pune and Maharashtra, India. DU-145 and Vero cells was cultured in Dulbecco's modified eagle's media, fortified with $10 \%$ fetal bovine serum and incubated under $5 \% \mathrm{CO}_{2}$ humidified incubator at $37^{\circ}$ until $70-80 \%$ confluence reached. The cells were dissociated with $0.2 \%$ trypsin, $0.02 \%$ EDTA in phosphate buffer saline solution. The stock cultures were grown initially in $25 \mathrm{~cm}^{2}$ tissue culture flasks, then in $75 \mathrm{~cm}^{2}$, and finally in $150 \mathrm{~cm}^{2}$ tissue culture flask and cell proliferation assay was carried out 96 well microtiter plates. The cells were seeded in 96 well plates in DMEM supplemented with $10 \%$ Fetal Bovine Serum (FBS). After $24 \mathrm{~h}$ of inoculation in humidified $\mathrm{CO}_{2}(5 \%)$ with air environment at $37^{\circ}$, when cells became 70-80\% confluent, then the cells were grown in 96 well plates for establishment of monolayer at density of $1 \times 10^{5}$ cells per well according to the instruction given in kit manual[ ${ }^{[25,26]}$. After achieving desired cell density, cells were treated with one third dilution series of various extract fractions $(4.12,12.35,37.04,111.1,333.3$ and $1000 \mu \mathrm{g} / \mathrm{ml})$ and incubated further for $24 \mathrm{~h}$. Then after next day, $20 \mu \mathrm{l}$ of MTT solution $(5 \mathrm{mg} / \mathrm{ml})$ were added in each well and plate was re-incubated for $4 \mathrm{~h}$. Finally, $100 \mu \mathrm{l}$ of DMSO:Isopropyl alcohol (IPA) (60:40) solubilizing mixture was added to dissolve formazan crystals. Then absorbance of the plate was measure at $570 \mathrm{~nm}$ by using a 96 well micro plate. Percentage cytotoxicity or 
percentage cell growth inhibition was calculated using equation. Percentage viability $=\left(A_{T}-A_{B}\right) /\left(A_{C}-A_{B}\right) \times 100$

Where, $\mathrm{A}_{\mathrm{T}}=$ Absorbance of treated cells (drug); $\mathrm{A}_{\mathrm{B}}=\mathrm{Absorbance}$ of blank (only media); $\mathrm{AC}=\mathrm{Absorbance}$ of control (untreated). Therefore, percentage cytotoxicity or percentage cell growth inhibition $=100$ percentage cell survival. The plot of percentage cell inhibition versus sample concentration was used to calculate the $50 \%$ Inhibition Concentration $\left(\mathrm{IC}_{50}\right)$. Selectivity Index (SI) was also calculated from the ratio of $\mathrm{IC}_{50}$ of Vero cells versus cancerous (DU-145) cells. SI values indicate selectivity of extract fraction in tested cells. Extract fractions with $\mathrm{SI}>3$ were measured to have high selectivity ${ }^{[27-29]}$. Data of percent cell growth inhibition were expressed as means of three independent observations $(\mathrm{n}=3)$. The $\mathrm{IC}_{50}$ was determined by interpolating concentration (X-axis) vs. percentage cell inhibition (Y-axis) by linear regression equation using Microsoft Excel, 2007, Microsoft Corporation, USA. Cytotoxicity (In vitro) analysis has become an essential part of drug discovery process because it is convenient, cost effective and predictive means of characterizing toxic effects of new chemical entities. The early and routine implementation of this analysis is evidence to its prognostic importance for humans ${ }^{[30]}$. In vitro cell line model is of at least equal concern to the human xenograft model ${ }^{[31]}$. Herbal medicine comprise a widespread substitute for cancer prevention and treatment worldwide ${ }^{[32-35]}$. Around sixty percent of anticancer medicines presently have isolated from medicinal plants. Recently, more than three thousand plants globally reported to have anticancer effects ${ }^{[36]}$. In emphasized with this, our result of percentage cell inhibition, $\mathrm{IC}_{50}$ and SI of extract fractions (EN1 to
EN6) of E. neriifolia leaves for both cells were shown in Table 1 and fig. 1 . In order to $\mathrm{IC}_{50}$ and SI results, extract fractions have been classified into 05 categories as described by Prayog et al. ${ }^{[28]}$. Firstly, potentially cytotoxic $\left(\mathrm{IC}_{50}\right.$ in DU-145<100 $\left.\mu \mathrm{g} / \mathrm{ml}\right)$ and high SI ( $\mathrm{SI} \geq 3$ ), no sample was found in this category. Secondly, moderate cytotoxic $\left(100 \mu \mathrm{g} / \mathrm{ml}<\mathrm{IC}_{50}\right.$ in DU-145 $<1000 \mu \mathrm{g} / \mathrm{ml}$ ) and high SI $(\mathrm{SI} \geq 3)$, only Doxo sample was found. Thirdly, moderate cytotoxic $\left(100 \mu \mathrm{g} / \mathrm{ml}<\mathrm{IC}_{50}\right.$ in DU-145 $\left.\leq 1000 \mu \mathrm{g} / \mathrm{ml}\right)$ and less SI $(\mathrm{SI}<3)$, the EN1, EN2 and EN3 samples were found. Fourthly, toxic to only Vero cells and it was EN1 and EN2. Lastly, non-toxic in DU-145 and Vero cells $\left(\mathrm{IC}_{50}>1000 \mu \mathrm{g} / \mathrm{ml}\right)$ and they were EN4, EN5 and EN6. Extract fractions in first 02 categories could be taken for further bioassay guided experimentation and highest SI indicate its ultimate potential for biopharmaceutical use among the tested extract fractions ${ }^{[28]}$. In line with above statement, no extract fraction was found in first 02 categories at the tested concentrations. Only doxorubicin standard drug sample was found in second category. As per earlier evidences on in vitro cytotoxicity studies on E. neriifolia isolates and extracts which suggested that studies were performed using murine B16F10 melanoma cell line only. These studies includes in vitro cytotoxicity of euphol isolated from triterpenoidal sapogenin fraction of E. neriifolia leaf was assessed using murine F10B16 melanoma cell line. Results of assay revealed that $50 \%$ inhibition concentration was $173.78 \mathrm{mg} / \mathrm{ml}^{[13]}$. Anticancer activity of methanolic extracts of E. neriifolia, Euphorbia hirta (E. hirta) and Euphorbia tirucalli (E. tirucalli) against B16F10 melanoma cancer cell line was performed. These plants showed significant cytotoxicity against B16F10

TABLE 1: PERCENTAGE CELL INHIBITION, IC ${ }_{50}$ AND SI OF EXTRACT FRACTIONS OF E. NERRIFOLIA AGAINST DU-145 AND VERO CELLS

\begin{tabular}{|c|c|c|c|c|c|c|c|c|c|c|c|c|c|c|}
\hline \multirow{2}{*}{$\begin{array}{l}\text { Conc. } \\
\mu \mathrm{g} / \mathrm{ml}\end{array}$} & \multicolumn{7}{|c|}{ DU-145 cells } & \multicolumn{7}{|c|}{ Vero cells } \\
\hline & EN1 & EN2 & EN3 & EN4 & EN5 & EN6 & Doxo & EN1 & EN2 & EN3 & EN4 & EN5 & EN6 & Doxo \\
\hline 4.12 & 9.15 & 12.12 & 2.26 & 2.25 & 2.26 & 1.55 & 15.24 & 1.64 & 2.31 & 1.67 & 1.98 & 0.35 & 0.35 & 0.65 \\
\hline 12.35 & 14.67 & 23.02 & 14.15 & 3.65 & 2.43 & 2.23 & 24.35 & 2.06 & 5.34 & 3.41 & 2.45 & 0.98 & 0.98 & 1.14 \\
\hline 37.04 & 22.36 & 34.13 & 22.56 & 8.45 & 3.56 & 2.65 & 41.37 & 6.34 & 13.05 & 7.23 & 6.34 & 1.22 & 1.23 & 1.57 \\
\hline 111.11 & 40.14 & 48.07 & 36.48 & 15.54 & 8.23 & 3.75 & 52.2 & 15.24 & 26.34 & 9.34 & 12.34 & 1.65 & 1.65 & 2.13 \\
\hline 333.33 & 58.5 & 66.15 & 47.18 & 14.65 & 12.65 & 12.24 & 63.1 & 32.21 & 34.24 & 16.34 & 15.32 & 2.65 & 2.04 & 3.62 \\
\hline 1000 & 70.39 & 76.09 & 66.28 & 44.55 & 46.45 & 36.05 & 71.24 & 46.21 & 52.31 & 36.35 & 45.34 & 25.34 & 18.32 & 22.31 \\
\hline \multicolumn{15}{|c|}{ Selectivity Index (S.I) } \\
\hline Samples & \multicolumn{2}{|c|}{ EN1 } & \multicolumn{2}{|c|}{ EN2 } & \multicolumn{2}{|c|}{ EN3 } & \multicolumn{2}{|c|}{ EN4 } & \multicolumn{2}{|c|}{ EN5 } & \multicolumn{2}{|c|}{ EN6 } & \multicolumn{2}{|c|}{ Doxo } \\
\hline S.I & \multicolumn{2}{|c|}{1.95} & \multicolumn{2}{|c|}{2.28} & \multicolumn{2}{|c|}{2.38} & \multicolumn{2}{|c|}{0.98} & \multicolumn{2}{|c|}{1.88} & \multicolumn{2}{|c|}{2.05} & \multicolumn{2}{|c|}{$>6.32^{\mathrm{B}}$} \\
\hline
\end{tabular}

DU-145: Human prostate adenocarcinoma cells; Vero: normal African green monkey kidney cells; EN1: Petroleum ether extract fraction; EN2: Toluene extract fraction; EN3: Chloroform extract fraction; EN4: Ethyl acetate extract fraction; EN5: $n$-butanol extract fraction; EN6: Aqueous extract fraction; Conc.: Concentration $(\mu \mathrm{g} / \mathrm{ml})$; Doxo: Doxorubicin; $\mathrm{IC}_{50}: 50 \%$ inhibition concentration; Data of percent cell growth inhibition were expressed as the means of three independent observations $(n=3)$. SI=IC ${ }_{50}$ of Vero cells $/ I C_{50}$ of DU-145 cells; ${ }^{\mathrm{A} I C_{50}}>1000 \mu \mathrm{gg} / \mathrm{ml}$ is considered to inactive; ${ }^{B} \mathrm{SI}$ referred to $\mathrm{SI}$, when $\mathrm{SI}$ value $>3$ indicates high selectivity. 


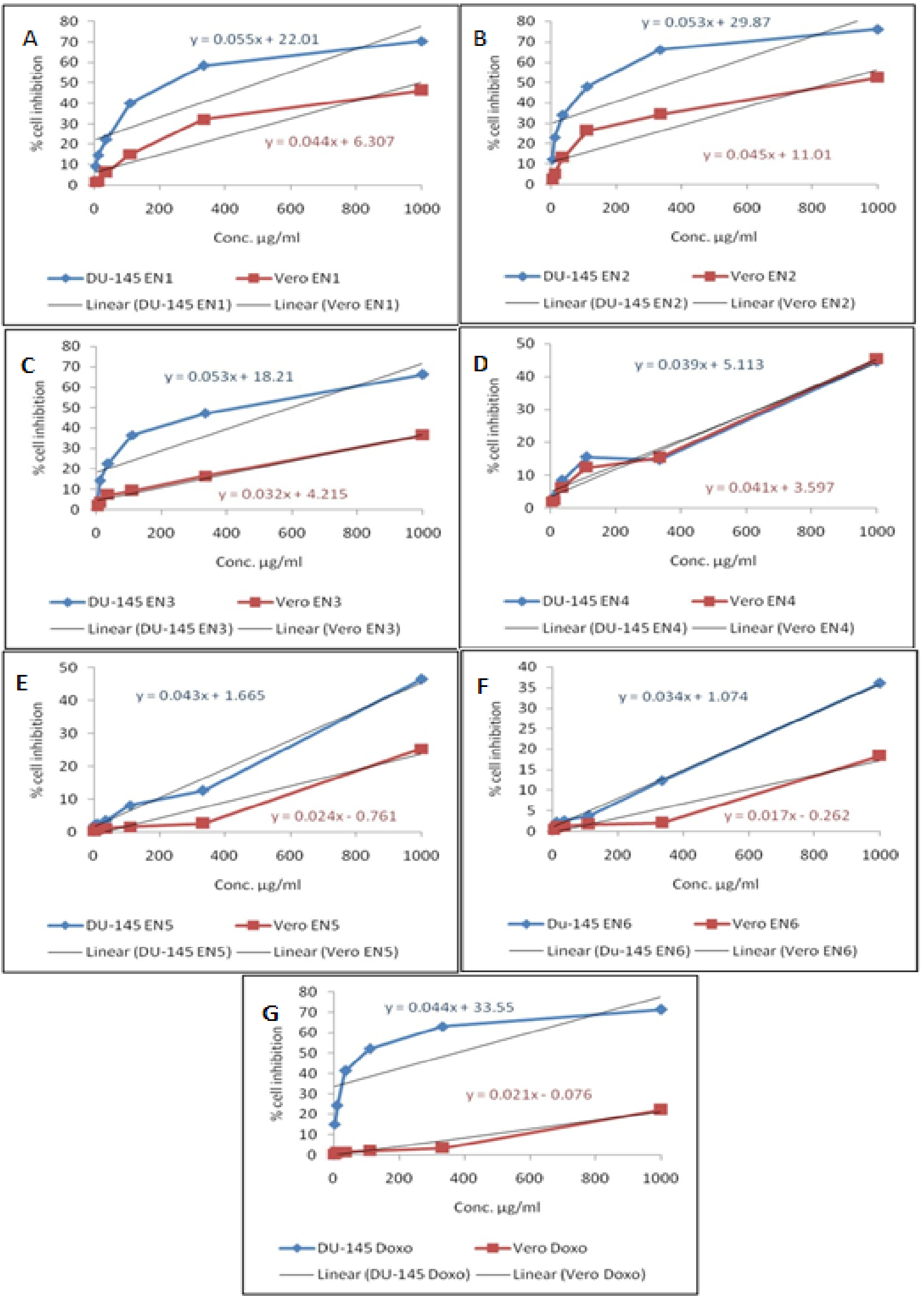

Fig. 1: Percentage cell inhibition of extract fractions of $E$. neriifolia against DU-145 and Vero cells. A: Percentage cell inhibition of EN1 extract fraction; B: Percentage cell inhibition of EN2 extract fraction; C: Percentage cell inhibition of EN3 extract fraction; D: Percentage cell inhibition of EN4 extract fraction; E: Percentage cell inhibition of EN5 extract fraction; F: Percentage cell inhibition of EN6 extract fraction; G: Percentage cell inhibition of doxorubicin 
melanoma cell line in concentration range 10-1000 ml using Sulforhodamine B (SRB) and MTT assay. Fifty percent inhibition concentration of methanolic extract of E. neriifolia, E. hirta and E. tirucalli was 198.26, 185.41 and 20.10 by SRB assay and 212.78, 240.98 and 237.07 by MTT assay. Methanolic extract of all these three plants showed significant activity against B16F10 melanoma cells ${ }^{[9]}$. Based on reported biological activities, the E. neriifolia extracts and isolates can be explored for their therapeutic potential by use of modern assay methods. Molecular mechanisms should be established for therapeutic applications ${ }^{[37]}$. It can be concluded that no other cells studies were documented yet on isolates and extract fractions of E. neriifolia by in vitro methods except murine $\mathrm{B} 16 \mathrm{~F} 10$ melanoma cells. Therefore, there is a need to carry forward these studies at higher concentrations of extract fractions (EN1 to EN6) in human prostrate adenocarcinoma (DU-145) and normal (Vero) cells. It can also be study by using other in vivo allograft and xenograft experimental animal models to confirm anti-proliferative or anti-cancer effects of these extract fractions.

\section{Acknowledgements:}

The authors would like to thankful to Head, Department of Pharmaceutical Biotechnology, S. K. Patel College of Pharmaceutical Education and Research, Ganpat University, Mehsana, Gujarat, India for providing the necessary facilities to this investigation.

\section{Conflict of interests:}

The authors declared no conflict of interest.

\section{REFERENCES}

1. Council of Scientific \& Industrial Research (India). The Wealth of India: a dictionary of Indian raw materials and industrial products. Council of Scientific and Industrial Research 1948:226-8.

2. Ved DK, Sureshchandra ST, Barve V, Srinivas V, Sangeetha S, Ravikumar K, et al. Plant details. Bengaluru: FRLHT's ENVIS Centre on Medicinal Plants 2016:49-116.

3. Chunekar KC. Illustrated Dravyaguna Vijnana. $2^{\text {nd }}$ ed. Varanasi: Chaukhambha Orientalia 2005:924-5.

4. The ayurvedic pharmacopoeia of India-I. Controller of publications. New Delhi 2001;1:100.

5. Kirtikar KR, Basu BD. Indian medicinal plants. $2^{\text {nd }}$ ed. Allahabad: Lalit Mohan Basu 2006;3:2201-4.

6. Sharma V, Pracheta PR, Singh L, Sharma V, Sharma SH. Anticarcinogenic potential of $E$. neriifolia leaves against $\mathrm{N}$-nitrosodiethylamine-induced nephrotoxicity in mice. J Biochem Cell Arch 2011;11(2):393-8.

7. Sharma V, Janmeda P. Chemopreventive role of E. neriifolia (Linn) and its isolated flavonoid against $\mathrm{N}$-nitrosodiethylamineinduced renal histopathological damage in male mice. Toxicol Int 2013;20(1):101.
8. Janmeda P, Sharma V, Singh L, Paliwal R, Sharma S, Yadav S, et al. Chemopreventive effect of hydroethanolic extract of $E$. neriifolia leaves against DENA-induced renal carcinogenesis in mice. Asian Pac J Cancer Prev 2011;12(3):677-83.

9. Babar RS, Kataware UP, Mali NN, Patil SB, Naikwade NS. In vitro cytotoxicity activity of $E$. hirta, E. tirucalli and $E$. neriifolia extract against B16F10 melanoma cell line. Invent Impact Ethnopharmacol 2012;3:15.

10. Patil SB, Magdum CS. Determination of LC50 values of extracts of E. hirta Linn and E. neriifolia Linn using brine shrimp lethality assay. Asian J Res Pharm Sci 2011;1(2):42-3.

11. Mali PY, Goyal S. HPTLC Densitometric Quantification of Kaempferol from Leaves of E. neriifolia. Ind J Pharm Edu Res 2020;54:921-27.

12. Roa DN, Row LR. The crystalline principles of Euphorbiaceae Part III. Curr Sci 1965;34(14):432.

13. Bigoniya P, Rana AC. Radioprotective and in vitro cytotoxic sapogenin from E. neriifolia (Euphorbiaceae) leaf. Tropic J Pharm Res 2009;8(6):521-30.

14. Sharma V, Janmeda P. Chromatography fingerprinting profile studies on the flavonoids of E. neriifolia (Linn.) leaves. Int $\mathbf{J}$ Drug Dev Res 2013;5(1):286-96.

15. Toume K, Nakazawa T, Hoque T, Ohtsuki T, Arai MA, Koyano $\mathrm{T}$, et al. Cycloartane triterpenes and ingol diterpenes isolated from E. neriifolia in a screening program for death-receptor expression-enhancing activity. Planta Med 2012;78(12):13707.

16. Liu JH, Latif A, Ali M, Zhang GP, Xiang WJ, Ma L, et al. Diterpenoids from E. neriifolia. Phytochem 2012;75:153-8.

17. Sharma V, Janmeda P. Extraction, isolation and identification of flavonoid from $E$. neriifolia leaves. Arab J Chem 2017;10(4):509-14.

18. Ferlay J, Shin HR, Bray F, Forman D, Mathers C, Parkin DM. Estimates of worldwide burden of cancer in 2008: GLOBOCAN 2008. Int J Cancer 2010;127(12):2893-917.

19. Whittemore AS, Kolonel LN, Wu AH, John EM, Gallagher RP, Howe GR, et al. Prostate cancer in relation to diet, physical activity, and body size in blacks, whites, and Asians in the United States and Canada. J Natl Cancer Inst 1995;87(9):65261.

20. Nelson WG, Angelo M. De Marzo, and William B. Isaacs. Mechanisms of disease. Prostate cancer. N Engl J Med 2003;349(4):366-81.

21. Ross RK, Henderson BE. Do diet and androgens alter prostate cancer risk via a common etiologic pathway? J Natl Cancer Inst 1994;86(4):252-55.

22. Kim SC, Wang J, Emery MS, Shin WG, Mulholland GW, Pui DY. Structural property effect of nanoparticle agglomerates on particle penetration through fibrous filter. Aerosol Sci Technol 2009;43(4):344-55.

23. Bhandari PR. Pomegranate (Punica granatum L). Ancient seeds for modern cure? Review of potential therapeutic applications. Int J Nutr Pharmacol Neural Dis 2012;2(3):171.

24. Mali PY, Panchal SS. Pharmacognostical and Physico-chemical Standardization of E. neriifolia Leaves. Pharmacognosy J 2017;9(5).

25. EZ count MTT cell assay kit (Product code: CCk003), HiMedia Laboratories Pvt. Ltd. Mumbai 2013.

26. Mosmann T. Rapid colorimetric assay for cellular growth and survival: application to proliferation and cytotoxicity assays. J Immunol Methods 1983;65(1-2):55-63.

27. Bézivin C, Tomasi S, Lohézic-Le Dévéhat F, Boustie J. Cytotoxic activity of some lichen extracts on murine and 
human cancer cell lines. Phytomed 2003;10(6-7):499-503.

28. Prayong P, Barusrux S, Weerapreeyakul N. Cytotoxic activity screening of some indigenous Thai plants. Fitoterapia 2008;79(7-8):598-601.

29. Mahavorasirikul W, Viyanant V, Chaijaroenkul W, Itharat A, Na-Bangchang K. Cytotoxic activity of Thai medicinal plants against human cholangiocarcinoma, laryngeal and hepatocarcinoma cells in vitro. BMC Complement Altern Med 2010;10(1):55.

30. Niles $\mathrm{AL}$, Moravec RA, Riss TL. In vitro viability and cytotoxicity testing and same-well multi-parametric combinations for high throughput screening. Curr Chem Genomics 2009;3:33-41.

31. Voskoglou-Nomikos T, Pater JL, Seymour L. Clinical predictive value of the in vitro cell line, human xenograft, and mouse allograft preclinical cancer models. Clin Cancer Res 2003;9(11):4227-39.

32. Mehta RG, Murillo G, Naithani R, Peng X. Cancer chemoprevention by natural products: how far have we come? Pharma Res 2010;27(6):950-61.

33. Desai AG, Qazi GN, Ganju RK, El-Tamer M, Singh J, Saxena AK, et al. Medicinal plants and cancer chemoprevention. Curr Drug Metabol 2008;9(7):581-91.

34. Guilford JM, Pezzuto JM. Natural products as inhibitors of carcinogenesis. Expert Opin Invest Drugs 2008;17(9):134152.

35. Soobrattee MA, Bahorun T, Aruoma OI. Chemopreventive actions of polyphenolic compounds in cancer. Biofactors 2006;27(1-4):19-35.

36. Dai J, Mumper RJ. Plant phenolics: extraction, analysis and their antioxidant and anticancer properties. Molecules 2010;15(10):7313-52.

37. Mali PY, Panchal SS. E. neriifolia L.: Review on botany, ethnomedicinal uses, phytochemistry and biological activities. Asian Pac J Trop Med 2017;10(5):430-8.. 